Г.І. Яровий (ДП завод «Електроважмаш»), Д.В. Ніконенко (ДП завод «Електроважсмаш»), acn. О.О. Шкурпела (УкрДАЗТ), канд. техн. наук І.О. Тукалов (НТУ «ХІІ»)

\title{
ПОБУДОВА МАТЕМАТИЧНОЇ МОДЕЛІ ЕЛЕКТРОПЕРЕДАЧІ ДИЗЕЛЬ-ПОЇЗДА ДЕЛ-02
}

\author{
Представив д-р техн. наук, професор А.П. Фалендищ
}

Ветуп, постановка задачі, аналіз останніх досліджень та публікацій. Серед останніх вітчизняних розробок рухомого складу є дизель-поїзд ДЕЛ-02, оснащений тяговим електроприводом на базі системи «інвертор напруги - асинхронний двигун».
Незважаючи на широке використання даного типу привода на різних рухомих одиницях, продовжуються інтенсивні дослідження щодо поліпшення його як технічних, так i експлуатаційних характеристик. При цьому, крім стендових 
та експлуатаційних досліджень, широко використовуються методи математичного моделювання [1-4], що дає змогу: проводити дослідження складної системи, якою $є$ i тягова електропередача дизельпоїзда ДЕЛ-02, з виключенням істотних або неістотних зв'язків; реалізовувати умови, недосяжні на практиці; прогнозувати стан системи.

Мета роботи полягає у визначенні основних підходів до розроблення математичної моделі тягової електропередачі дизель-поїзда ДЕЛ-02 для проведення дослідження як штатних, так i нештатних режимів ऑiі роботи 3 метою

\section{Основні параметри дизель-поїзда}

покращення технічних та експлуатаційних характеристик.

Основна частина. Функціональна схема тягової електропередачі. Дизельпоїзд ДЕЛ-02 вітчизняного виробництва обладнаний тяговим приводом змінного струму 3 асинхронними тяговими двигунами АД906У1, перетворювачами частоти із загальною ланкою постійного струму, мікропроцесорною системою керування та силовим модулем "РошегРаск", виробництва фірми MTU (Німеччина). Схема містить джерела енергопостачання допоміжних систем та опалення салонів. Дизель-поїзд оснащений реостатним гальмуванням.
Рід служби

Складеність дизель-поїзда:

головних (моторних) вагонів

причіпних вагонів

Осьова формула головного вагона

Ширина колії, мм

Діаметр колеса по колу кочення, мм

при нових бандажах

при повністю зношених бандажах

Маса тари з екіпіровкою, т, не більше

головного (моторного) вагона

причіпного вагона

Кількість місць для сидіння, од., не менш:

$$
\begin{aligned}
& \text { в дизель-поїзді } \\
& \text { в головному (моторному) вагоні } \\
& \text { в причіпному вагоні }
\end{aligned}
$$

пасажирський

\section{2}

1

20-22

1520

950

870

64

45

344

104

136

Статичне навантаження від колісної пари на колію, при максимальній населеності, тс, не більше моторного (головного) вагона причіпного вагона

Номінальна потужність дизеля, кВт

Система пуску дизеля - електрична від акумуляторної батареї напругою 
Як приводний двигун силового модуля "PowerPack" виробництва фірми MTU використовується дизель 12U183TB13. Дизельний двигун чотиритактний 3 рідинним охолодженням, лівим обертанням, безпосереднім вприском палива.

Тяговий генератор SDV67.29-12 $є$ синхронна електрична машина 3 незалежним збудником, 3 двома трифазними статорними обмотками, що зміщені на 30 електричних градусів. Збудження збудника тягового генератора здійснюється від мікропроцесорної системи керування.

Тяговий електродвигун АД-906У 1 являє собою трифазну асинхронну реверсивну електричну машину 3 короткозамкненим ротором, 3 самовентиляцією. Виконаний у кліматичному виконанні У1. Група умов експлуатації в частині впливу механічних факторів зовнішнього середовища М26 згідно $з$ ГОСТ 175161-90. Підвішування тягового двигуна - опорно-рамне. Також він обладнаний датчиком частоти обертання типу KMG-2H та датчиком температури статорної обмотки типу Pt100. Живлення тягових двигунів забезпечують перетворювачі частоти (ПЧ) типу МПЧ-Т2ТП-200-1,15к-50-У3, кожен 3 яких складається 3 діодного випрямляча 3 керованим ключем для реостатного гальмування, ємнісного фільтра, трифазного інвертора напруги на IGBTмодулях. При зміні частоти основної гармоніки від 0,4 до 18 Гц вихідна напруга кожного ПЧ регулюється методом широтно-імпульсного регулювання пропорційно сигналу глибини модуляції від системи керування. Подальше підвищення вихідної напруги реалізується системою збудження тягового генератора. Спрощена функціональна схема тягової електропередачі дизель-поїзда ДЕЛ-02 показана на рис. 1.

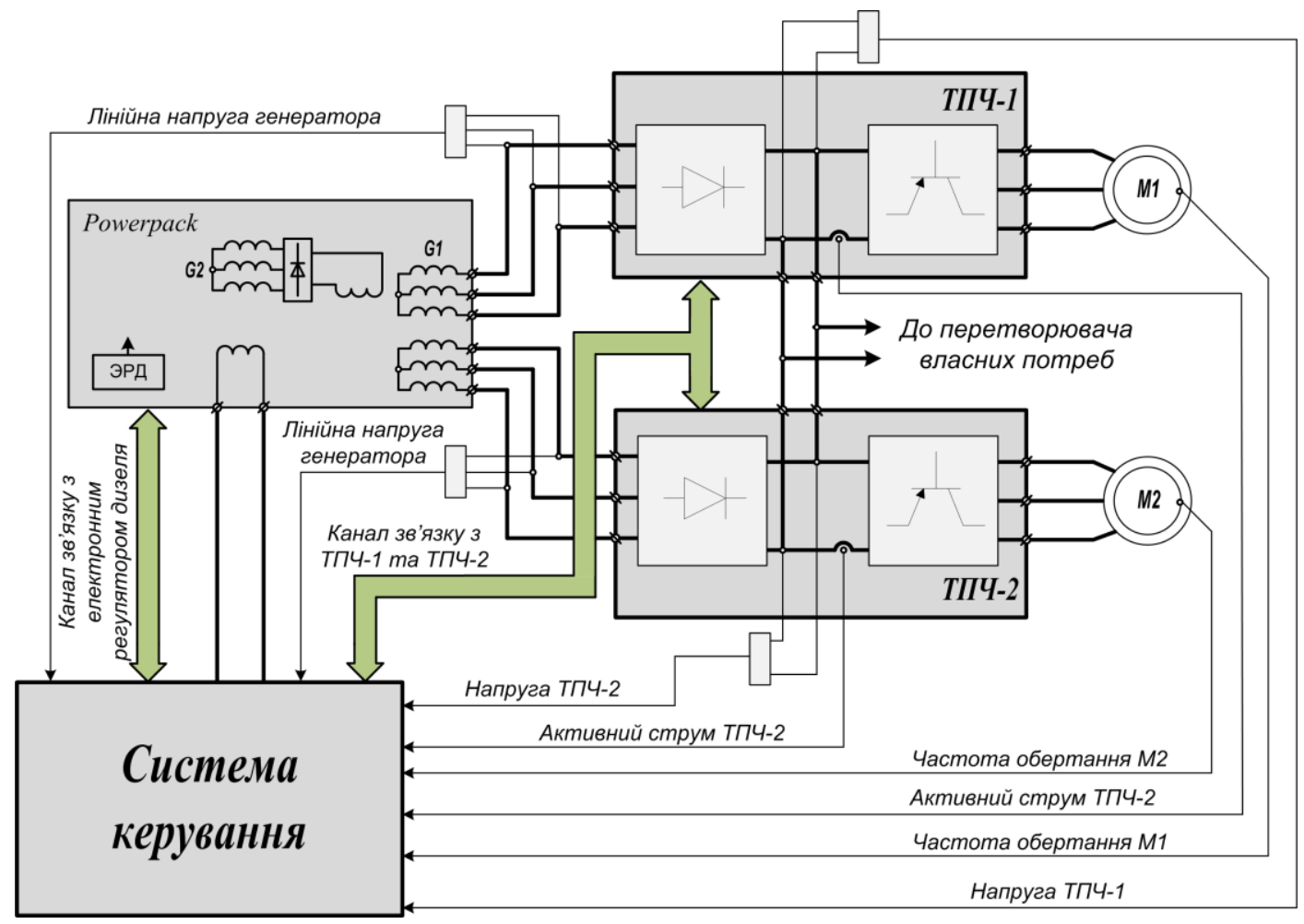

Рис. 1. Функціональна схема тягової електропередачі дизель-поїзда ДЕЛ-02 


\section{Особливість вибору моделі} асинхронного тягового електродвигуна (АД). Електричні машини змінного струму (зокрема, асинхронні і синхронні) в загальному випадку $\epsilon$ нелінійними багатомірними об'єктами 3 досить складною структурою, тому аналіз процесів, що протікають у них, методом математичного моделювання практично в ycix випадках пов'язаний iз певною попередньою ідеалізацією об'єкта досліджень. При математичному дослідженні всі параметри машини повинні мати однаковий "масштаб", тобто бути приведеними до єдиного кола (до певної номінальної напруги). При цьому найбільш часто всі параметри приводять до кола статора машини, i тільки в окремих випадках (насамперед керування машиною з боку ротора) - до кола ротора.

Коректність прийнятих допущень повинна бути суворо обгрунтована, а в ряді випадків, у залежності від мети досліджень, вплив факторів, якими зневажили, повинен бути урахований більш або менш точно. Саме тому відомі математичні моделі машин змінного струму відрізняються одна від одної перш за все складом зроблених припущень.

Вирішуючи завдання управління машинами змінного струму, дуже часто використовують певні координатні перетворення (перетворення Парка-Горєва) 3 метою подання математичного опису машини змінного струму у більш простій формі. Таким чином, модель однієї і тієї ж машини, в залежності від завдань досліджень, може відрізнятися системою координат, структурою, складом вхідних і вихідних параметрів. Ці фактори обираються також з урахуванням принципу управління, обраних регульованих координат та заданого джерела живлення.

Традиційно при аналізі роботи систем електричних передач відносно електричних машин на першому етапі приймаються такі припущення, які вказують на ступінь ідеалізації об'єкта:
- магніторушійні сили розподілені синусоїдально вздовж кола рівномірного повітряного зазора (тобто відсутні вищі гармоніки магнітного потоку);

- параметри обмоток машини $\epsilon$ зосередженими (геометричні розміри машини суттєво менші за довжину електромагнітної хвилі);

- електрична машина $\epsilon$ ненасиченою (магнітні властивості матеріалу магнітопроводу лінійні);

- втрати в сталі статора i ротора відсутні (струм намагнічування має чисто індуктивний характер);

- машина $€$ симетричною (усі обмотки окремо статора $\mathrm{i}$ ротора $\epsilon$ однаковими, розташовані у просторі суворо симетрично);

- комплексні опори обмоток не мають ємнісних складових (електростатичне поле в обмотках та між обмотками відсутне);

- відсутнє явище витиснення струму (параметри обмоток не $\epsilon$ функціями режиму роботи машини).

За необхідності певне явище повинно бути ураховано за можливості без зайвого ускладнення моделі.

Також розрізняють способи моделювання асинхронного двигуна залежно від виду системи координат на рівняння у фазних та ортогональних координатах, останні у свою чергу можуть бути орієнтованими або нерухомими.

Рівняння АД у фазних координатах описують процеси в асинхронній машині, дозволяючи при цьому не відходити від фізичної сутності цих процесів. За допомогою такої моделі можливе також якісне дослідження роботи АД за умов несиметрії АД (на рис. 2 як приклад наведені величини активного опору обмоток статора 8 АД) або джерела живлення (штатна несиметрія або несиметричні режими), при живленні АД від неідеального джерела живлення (джерело несинусоїдальної напруги). 
Проте такій моделі властивий той недолік, що вона містить періодичні коефіцієнти у диференційних рівняннях, що робить неможливим аналітичне їх розв'язання і значно збільшує тривалість їх числового розв'язання. Тому для спрощення математичної моделі необхідно переходити до моделювання двигуна в ортогональних двофазних координатах.
Метою моделювання АД в ортогональних двофазних координатах $\epsilon$ створення моделі АД, еквівалентної за своїми основними властивостями об'єкту і його моделі у фазних координатах, котра у той же час $\epsilon$ більш простою і тому більш зручною у моделюванні і придатною до синтезу ефективних алгоритмів управління АД.

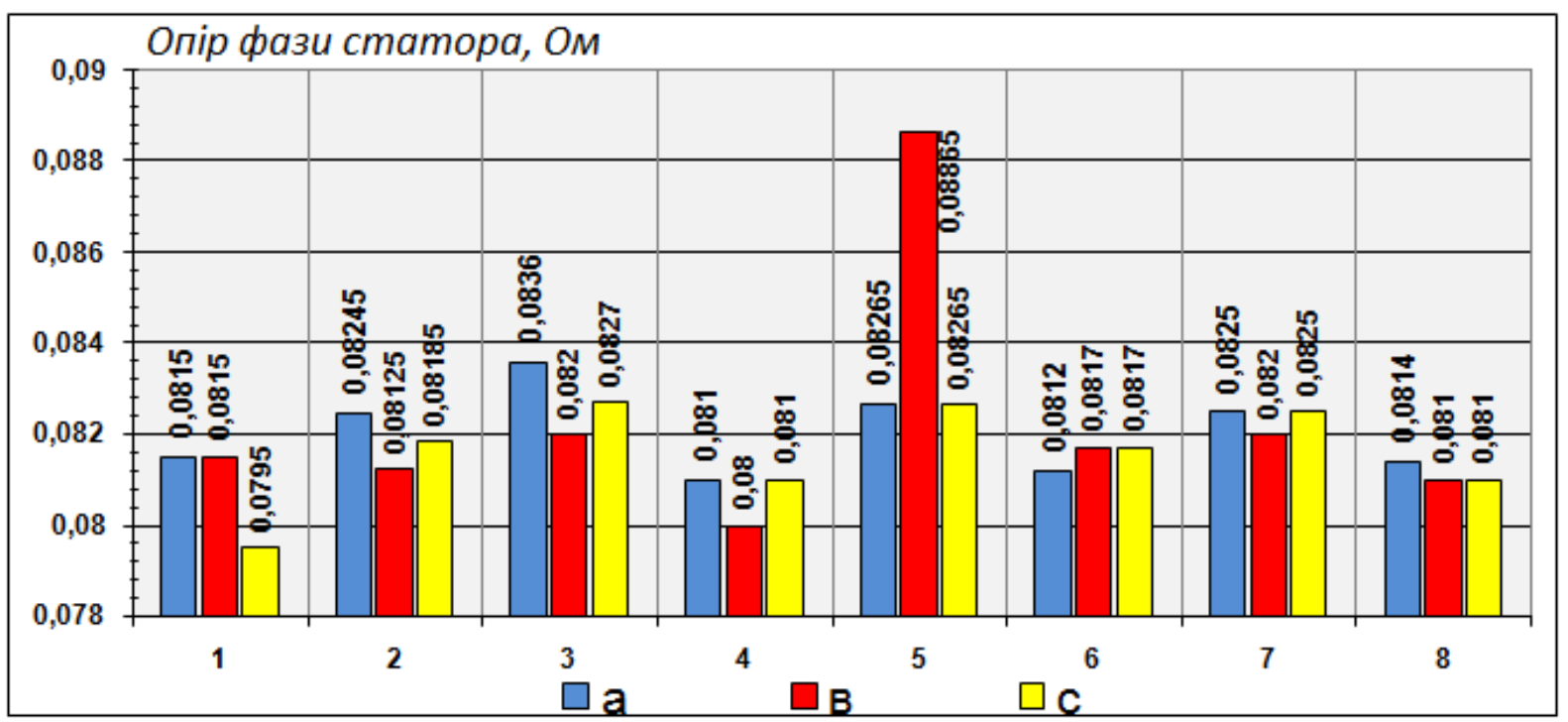

Рис. 2. Значення активного опору фаз статорів 8 двигунів АД-906

Стаціонарні системи координат статора $\alpha, \beta$ i ротора $\mathrm{u}, \mathrm{v} \in$ найбільш близькими до моделі АД у фазних координатах, тому використовуються як альтернатива моделі у фазних координатах, маючи таку основну перевагу, як більша простота, при аналізі миттєвих значень електромагнітних величин відповідно статора і ротора.

Синхронна система координат $x, y$ більше спрямована на аналіз амплітудних (або ефективних) значень електромагнітних величин статора i ротора в системах скалярного (параметричного, частотного) управління АД.

Оріснтовані системи координат використовуються, як правило, за необхідності організації векторного управління за певною електромагнітною відповідною величиною АД. Слід також відзначити, що за умови $\omega \mathrm{k}=\omega \mathrm{s}$ система координат вже буде непрямо орієнтованою за векторами, що визначають живлення АД (вектори напруги статора та ротора) [5].

Слід відзначити, що, в принципі, модель АД може бути складена так, що там будуть фігурувати складові лише одного вектора, i навіть так, що сигнал електромагнітного моменту буде визначатись лише за відомими вхідними сигналами складових напруги статора, але 3 оглядом на суттєву нелінійність АД така структура не зможе бути використана для синтезу високодинамічних систем асинхронного тягового електроприводу i вирішення завдання сукупного управління електромагнітним моментом i швидкістю АД [5]. 
Враховуючи вищесказане, можна відмітити таке: для повноцінного дослідження тягового електроприводу слід мати декілька математичних моделей тягового двигуна для оцінки швидкоплинних процесів та повільно протікаючих процесів у складі всього поїзда.

Пакет Simulink [6] дозволяє проводити дослідження (моделювання у часі) поведінки динамічних лінійних та нелінійних систем, причому складання «програми» та введення характеристик систем можна здійснювати в діалоговому режимі, шляхом складання на екрані схеми з'єднання елементарних (стандартних чи користувальницьких) ланок. Такий процес складання називають візуальним програмуванням.

Модель, що імітує роботу асинхронного двигуна 3 короткозамкненим (чи фазним) ротором, складена на основі математичних рівнянь та схеми заміщення (рис. 3).

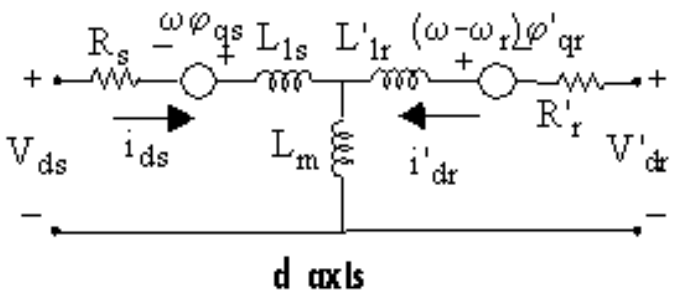

Рис. 3. Схема заміщення асинхронного двигуна з бібліотеки MATLAB

$$
\left.\begin{array}{l}
V_{q s}=R_{s} i_{q s}+\frac{d \phi_{q s}}{d t}+\omega \phi_{d s} ; \\
V_{d s}=R_{s} i_{d s}+\frac{d \phi_{d s}}{d t}-\omega \phi_{q s} ; \\
V_{q r}^{\prime}=R_{r}^{\prime} i_{q r}^{\prime}+\frac{d \phi_{q r}}{d t}+\omega \phi_{d r}^{\prime}+\left(\omega-\omega_{r}\right) \phi_{d r}^{\prime} ; \\
V_{d r}^{\prime}=R_{r}^{\prime} i_{d r}^{\prime}+\frac{d \phi r_{d r}}{d t}+\omega \phi_{d r}^{\prime}-\left(\omega-\omega_{r}\right) \phi_{q r}^{\prime} ; \\
T_{e}=1.5 p\left(\phi_{d s} i_{q s}-\phi_{q s} i_{d s}\right)
\end{array}\right\}
$$

де

$$
\begin{array}{ll}
\phi_{q s}=L_{s} i_{q s}+L_{m} i_{q r}^{\prime} & \\
\phi_{d s}=L_{s} i_{d s}+L_{m} i_{d r}^{\prime} & L_{s}=L_{l s}+L_{m} \\
\phi_{q r}^{\prime}=L_{r}^{\prime} i_{q r}^{\prime}+L_{m} i_{q s} & L_{r}=L_{l r}+L_{m} \\
\phi_{d r}^{\prime}=L_{r}^{\prime} i_{d r}^{\prime}+L_{m} i_{d s} &
\end{array}
$$

$R_{s}-$ активний фазний опір обмотки статора, Ом;

$R_{r}{ }_{r}$ - приведений активний фазний опір обмотки ротора, Ом;

$i_{d s}, i_{q s}-$ фазний струм обмотки статора по повздовжній та поперечній осі відповідно, А;

$i_{d r}, \quad i_{q r}^{\prime}-$ приведений фазний струм обмотки ротора по повздовжній та поперечній осі відповідно, А; 
$T_{e}$ - електромагнітний момент двигуна, Нм;

$L_{s}, L_{r}-$ індуктивності статора та ротора відповідно, Гн;

$L_{m}-$ взаємна індуктивність, Гн;

$L_{l s}, L_{l r}-$ індуктивності розсіяння статора та ротора відповідно, Гн;

$\omega$ - синхронна частота обертання, рад/с;

$\omega_{r}$ - частота обертання ротора, рад/с;

$\phi_{d s}, \phi_{q s}-$ потокозчеплення фази статора по повздовжній та поперечній осі відповідно, Вб; $\phi{ }_{d r}, \phi{ }^{\prime}{ }_{q r}$ - приведене потокозчеплення фази ротора по повздовжній та поперечній осі відповідно, Вб;

$V_{d s}, \quad V_{q s}$ - підведена фазна напруга обмотки статора по повздовжній та поперечній осі відповідно, В;

$V_{d r}^{\prime}, V_{q r}^{\prime}$ - приведена підведена фазна напруга обмотки ротора по повздовжній та поперечній осі відповідно, В.

Для проведення порівняльної оцінки була розроблена модель (рис. 4) асинхронного двигуна на базі рівнянь у нерухомій системі координат.

$$
\begin{aligned}
& u_{S \alpha}=r i_{S \alpha}+\dot{L}_{S} \frac{d i_{S \alpha}}{d t}-\frac{k_{R}}{T_{R}} \psi_{R \alpha}-k_{R} p \omega_{m} \psi_{R \beta}, \\
& u_{S \beta}=r i_{S \beta}+\dot{L}_{S} \frac{d i_{S \beta}}{d t}-\frac{k_{R}}{T_{R}} \psi_{R \beta}+k_{R} p \omega_{m} \psi_{R \alpha} \text {, } \\
& 0=-k_{R} R_{R} i_{S \alpha}+\frac{1}{T_{R}} \psi_{R \alpha}+\frac{d \psi_{R \alpha}}{d t}+p \omega_{m} \psi_{R \beta}, \\
& 0=-k_{R} R_{R} i_{S \beta}+\frac{1}{T_{R}} \psi_{R \beta}+\frac{d \psi_{R \beta}}{d t}-p \omega_{m} \psi_{R \alpha}, \\
& M=\frac{3}{2} p \cdot k_{R}\left(\psi_{R \alpha} i_{S \beta}-\psi_{R \beta} i_{S \alpha}\right), \\
& J \frac{d \omega_{m}}{d t}=M-M_{C} .
\end{aligned}
$$

Для створення моделі із системи рівнянь (2) виділяються струми та потокозчеплення і система рівнянь набуває вигляду:

$$
\left.\begin{array}{l}
i_{S \alpha}=\left(u_{S \alpha}-\frac{k_{R}}{T_{R}} \psi_{R \alpha}+k_{R} p \omega_{m} \psi_{R \beta}\right) \frac{1}{r\left(1+T_{S} s\right)}, \\
i_{S \beta}=\left(u_{S \beta}+\frac{k_{R}}{T_{R}} \psi_{R \beta}-k_{R} p \omega_{m} \psi_{R \alpha}\right) \frac{1}{r\left(1+T_{S} s\right)}, \\
\psi_{R \alpha}=\left(k_{R} R_{R} i_{S \alpha}-p \omega_{m} \psi_{R \beta}\right) \frac{T_{R}}{\left(1+T_{R} s\right)}, \\
\psi_{R \beta}=\left(k_{R} R_{R} i_{S \beta}+p \omega_{m} \psi_{R \alpha}\right) \frac{T_{R}}{\left(1+T_{R} s\right)}, \\
M=\frac{3}{2} p \cdot k_{R}\left(\psi_{R \alpha} i_{S \beta}-\psi_{R \beta} i_{S \alpha}\right), \\
\omega_{m}=\left(M-M_{C}\right) \frac{1}{J S} .
\end{array}\right\}
$$


де

$$
\begin{array}{lll}
\mathrm{r}=\mathrm{R}_{\mathrm{S}}+\frac{\mathrm{L}_{\mathrm{m}}^{2}}{\mathrm{~L}_{\mathrm{R}}^{2} \mathrm{R}_{\mathrm{R}}} & \mathrm{T}_{\mathrm{R}}=\frac{\mathrm{L}_{\mathrm{R}}}{\mathrm{R}_{\mathrm{R}}} & \overline{\mathrm{T}_{\mathrm{S}}^{\prime}}=\frac{\mathrm{L}_{\mathrm{S}}}{\mathrm{r}} \\
\mathrm{L}_{\mathrm{S}}=\mathrm{L}_{\mathrm{S}}-\frac{\mathrm{L}_{\mathrm{m}}^{2}}{\mathrm{~L}_{\mathrm{R}}} & \mathrm{k}_{\mathrm{R}}=\frac{\mathrm{L}_{\mathrm{m}}}{\mathrm{L}_{\mathrm{R}}}
\end{array}
$$

$R_{s}-$ активний фазний опір обмотки статора, $O M$;

$R_{r}{ }_{r}$ - приведений активний фазний опір обмотки ротора, $O M$;

$i_{s \omega}, i_{s \beta}-$ фазний струм обмотки статора по повздовжній та поперечній осі відповідно, $A$;

$p$ - кількість пар полюсів машини, од;

$J$ - момент інерції приведений до валу двигуна, $\kappa 2 / \mathrm{M}^{2}$;
$M, M_{c}$ - електромагнітний момент та момент опору двигуна, $H$ м;

$L_{s}^{\prime}$ - індуктивності статора та ротора відповідно, $Г$;

$\omega_{m}-$ частота обертання ротора, $\mathrm{pad} / \mathrm{c}$

$\psi_{R \alpha}, \psi_{R \beta}-$ потокозчеплення фази ротора по осі $\alpha$ та $\beta, B б$

$U_{s \alpha}, U_{s \beta}-$ підведена фазна напруга обмотки статора по повздовжній та поперечній осі відповідно, $B$.

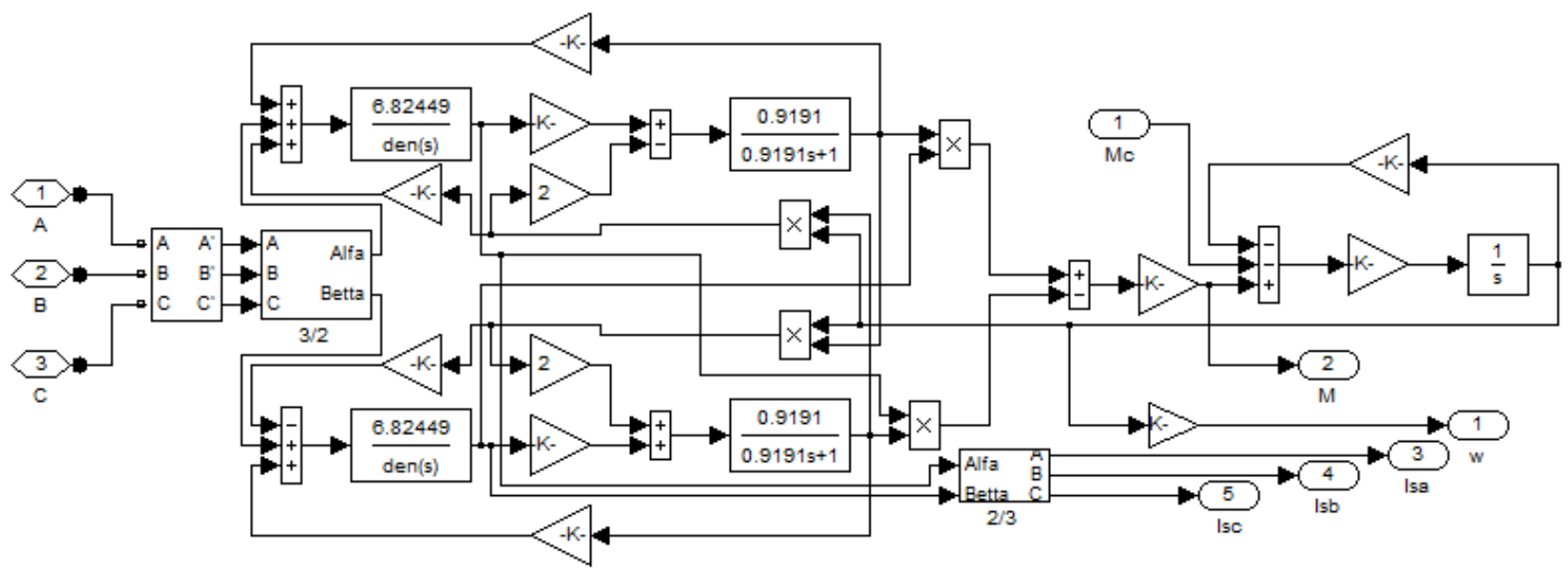

Рис. 4. Модель асинхронного двигуна у нерухомій системі координат, що складена за (3)

Відповідність моделей АД реальному АД-906 перевірялась шляхом порівняння даних моделювання режимів короткого замикання та холостого ходу 3 експериментально отриманими значеннями (див. рис. 5,6)

Як ілюстрація, на рис.7 показано результати моделювання прямого пуску АД для двох способів подання АД. 


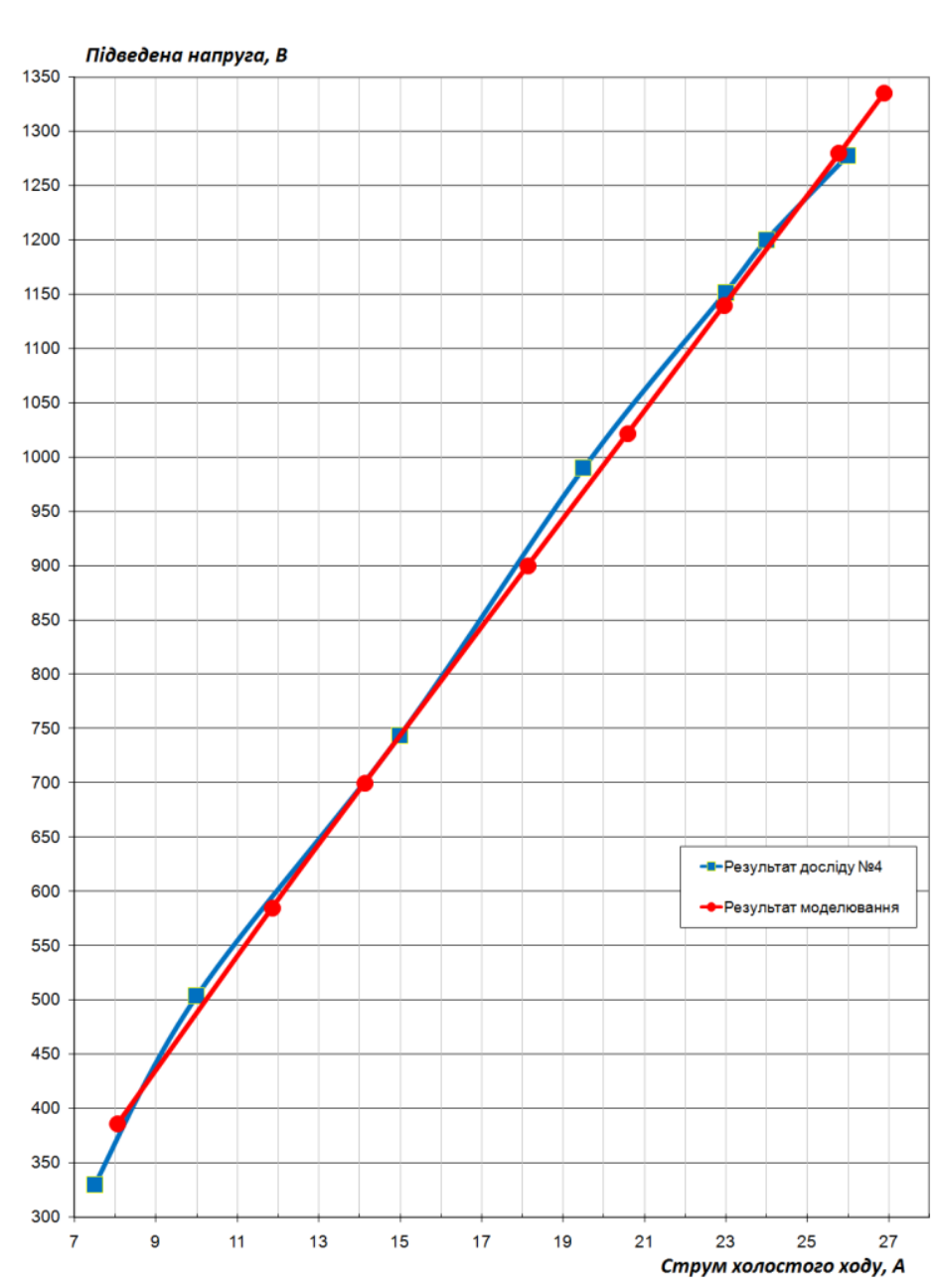

Рис. 5. Результати моделювання холостого ходу

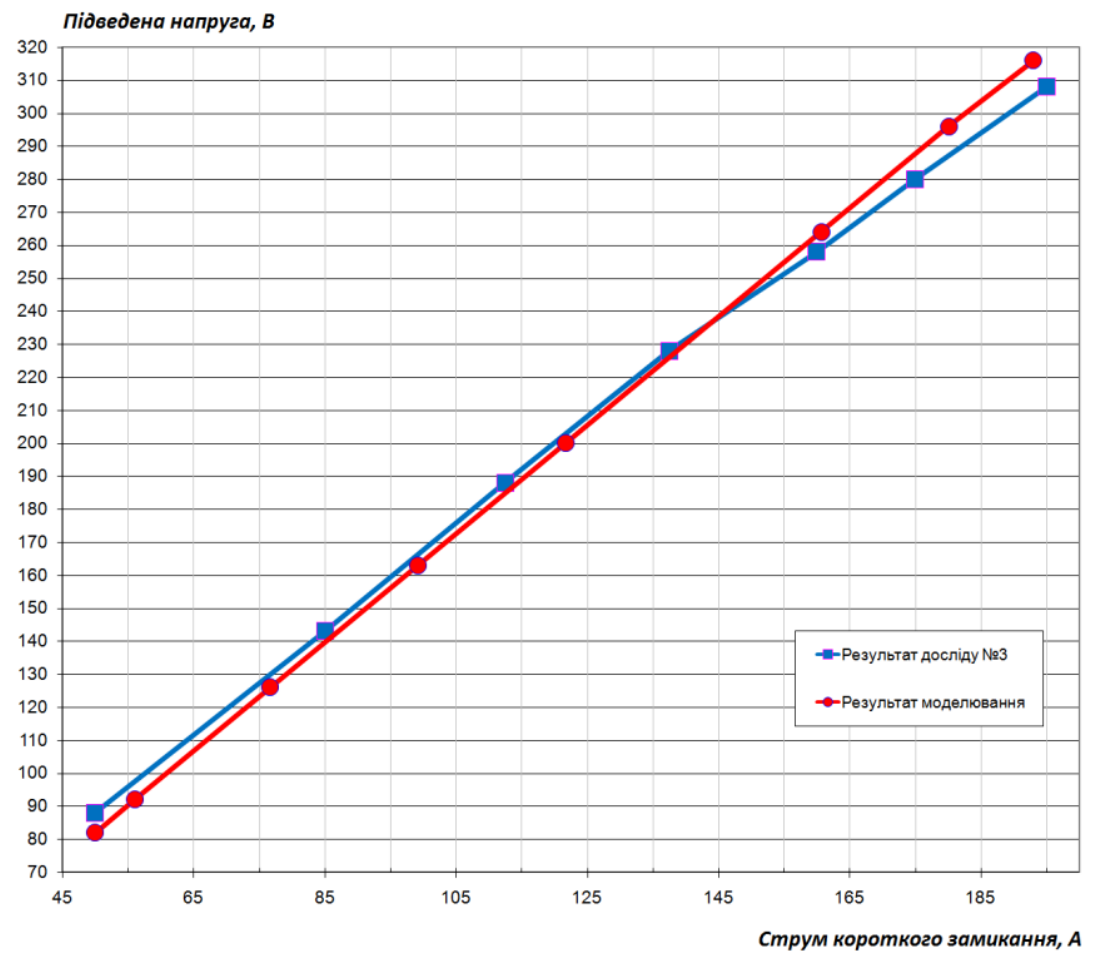

Рис. 6. Результати моделювання короткого замикання 

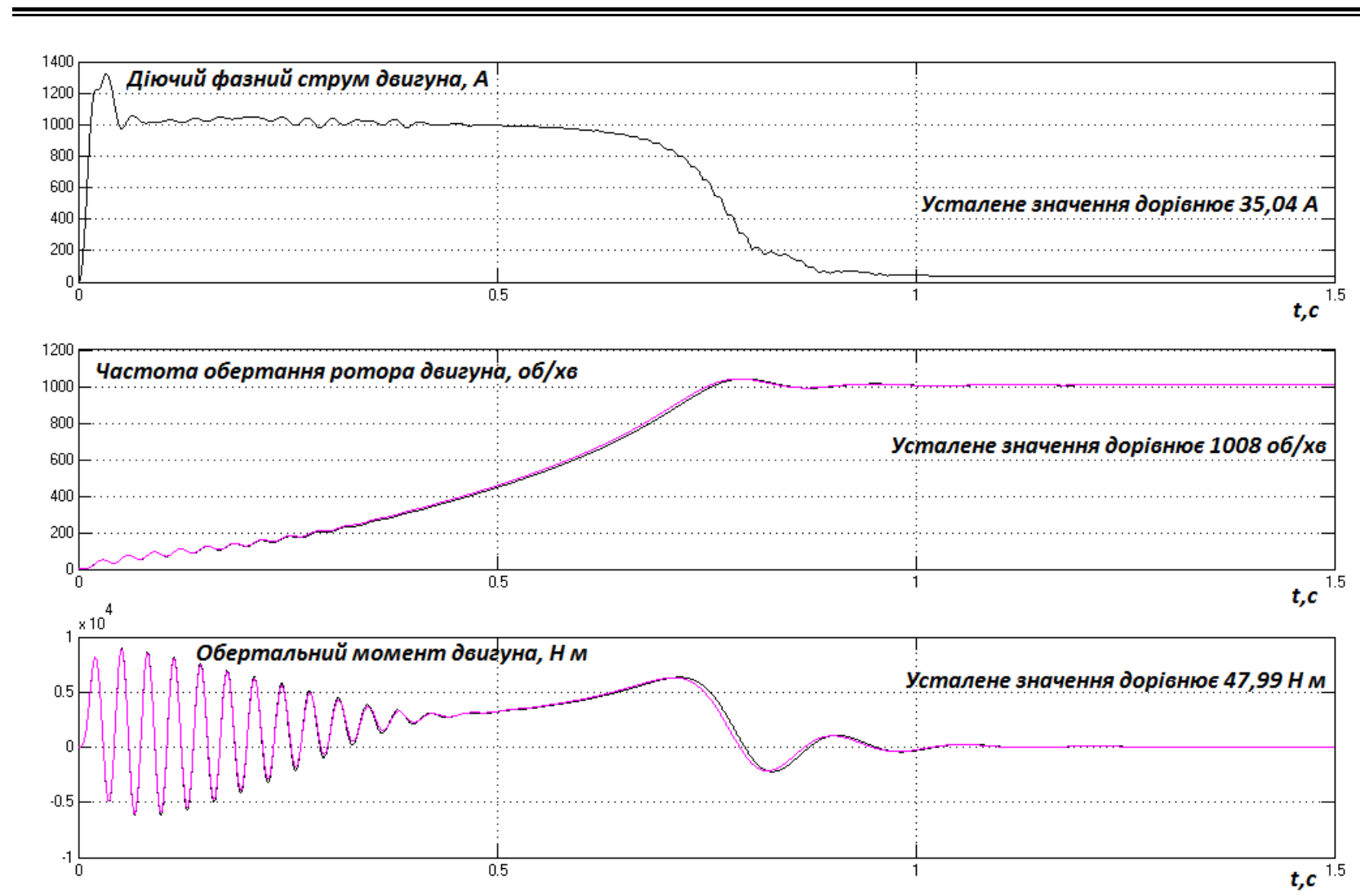

Рис. 7. Результати моделювання прямого пуску АД

Висновки. Розглянуті основні нештатних режимів роботи. Дослідження підходи до розроблення математичної моделі елементів тягової електропередачі дизель-поїзда ДЕЛ-02, які дозволять проводити дослідження як штатних, так i на основі математичної моделі сприяють уточненню тягових характеристик тягової електропередачі дизель-поїзда ДЕЛ-02.

\section{Список літератури}

1. Басов, Г.Г. Прогнозування розвитку дизель-поїздів для залізниць України [Текст] / Г.Г. Басов. - Харків: Апекс+, 2004. - Ч. 1. - 240 с.

2. Андрієнко, П.Д. Порівняльний аналіз регуляторів системи керування струмом тягового частотно - керованого електропривода дизель-поїзда ДЕЛ-02 [Текст] / П.Д. Андрієнко, Д.О. Кулагін, О.С. Качур // Електромашинобудування та електрообладнання. - 2010. - № 75. - С. 32-36.

3. Носков, В.І. Створення тягового електроприводу моторвагонних поїздів на базі сучасних інформаційних технологій [Текст]: автореф. дис. ... д-ра техн. наук / Носков Валентин Іванович. - Харків: НТУ «ХПІ», 2009. - 37 С.

4. Кулагін, Д.О. Підвищення ефективності роботи тягової електропередачі дизельпоїздів ДЕЛ-02 [Текст]: автореф. дис. ... канд. техн. наук : 05.22.07 / Кулагін Дмитро Олександрович;. - К.: ДП "Держ. н.-д. центр залізн. трансп. України", 2011. — 18 с.

5. Пересада, С.M. Векторное управление в асинхронном электроприводе: аналитический обзор [Текст] // Сб. науч. трудов. Серия “Электротехника и энергетика". Донецк: ДонГТУ, 1999. - Вып. 4. - С. 8-20. 
6. Дьяконов, В.П. MATLAB 6.5 SP1/7+Simulink 5/6 в математике и моделировании. Серия «Библиотека профессионала» [Текст] / В.П. Дьяконов. - М.:СОЛОН-Пресс, 2005. $576 \mathrm{c}$.

7. Алексеев, В.В. Выбор типа модели асинхронного двигателя при компьютерном моделировании электромеханических процессов, протекающих в частотных электроприводах с алгоритмами скалярного и векторного управления [Электронный ресурс] / В.В. Алексеев, В.И. Вершинин, А.Е. Козярук, В.Н. Язев // Онлайн Электрик: Электроэнергетика. Новые технологии, 2012. - Режим доступа: URL: http://www.online-electric.ru/articles.php?id=11

8. Micromaster 440. Руководство по эксплуатации. Документация пользователя. Издание A1 [Текст]. - Nürnberg.: Siemens AG 2007. - 140 с.

9. Ефименко, Е.И. Новые методы исследования машин переменного тока и их приложения [Текст] / Е.И. Ефименко. - М.: Энергоатомиздат, 1993. - 288 с.

10. Максимкин, В.Л. Разработка и применение математических моделей асинхронных двигателей с учетом случайного характера нагрузки [Текст] / В.Л. Максимкин. - М.: МЭИ, 1986.

11. Нгуен Мань Зуй. Динамика асинхронных машин в анормальных режимах [Текст] / Нгуен Мань Зуй. - М., 1986.

12. Зверев, К.А. Исследование волновых процессов в частотно-регулируемом асинхронном двигателе [Текст] / К.А. Зверев. - М.: МЭИ, 2000.

13. Амбрацумова, Т.Т. Макромоделирование асинхронных машин с учетом динамики [Текст] / Т.Т. Амбрацумова. - М.: Издательство МЭИ, 2002. - 40 с.

Ключові слова: електропередача, дизель-поїзд, асинхронний тяговий електродвигун, математична модель, холостий хід, коротке замикання.

\section{Анотаціï}

Розглянуто актуальне питання щодо визначення основних підходів до розроблення математичної моделі тягової електропередачі дизель-поїзда ДЕЛ-02 для проведення дослідження як штатних, так і нештатних режимів ії роботи з метою покращення технічних та експлуатаційних характеристик дизель-поїзда. Актуальність даної роботи полягає у визначенні основних підходів до повноцінного дослідження тягового електроприводу. Для цього слід мати декілька математичних моделей тягового двигуна для оцінки швидкоплинних процесів та повільно протікаючих процесів у складі всього поїзда.

Рассмотрен актуальный вопрос по определению основных подходов к разработке математической модели тяговой электропередачи дизель-поезда ДЕЛ-02 для проведения исследования как штатных, так и нештатных режимов ее работы с целью улучшения технических и эксплуатационных характеристик дизель-поезда. Актуальность данной работы заключается в определении основных подходов для полноценного исследования тягового электропривода. Для этого следует иметь несколько математических моделей тягового двигателя для оценки быстротекущих процессов и медленно протекающих процессов в составе всего поезда.

In the article а актуальный question is examined on determination of basic approaches on development of mathematical model of hauling electricity transmission of дизель-поезда оf DEL02 for the leadthrough of research both regular and nonpermanent, its office hours with the purpose of improvement of technical and operating descriptions a diesel is trains. Actuality of this work consists in determination of basic approaches for valuable research of hauling electromechanic. For this purpose it is necessary to have a few mathematical models of hauling engine for the estimation of fleeting processes and slowly flowings processes in composition all of train. 